\title{
HLUBOKÁ A PODNĚTNÁ ANALÝZA FUNGOVÁNÍ EVROPSKÉ UNIE Z POHLEDU TEORIE VEŘEJNÉ VOLBY
}

\section{Luboš Smrčka*}

\section{Marek Loužek: Evropská integrace z pohledu teorie veřejné volby}

Praha: Karolinum, 2017. 1. vydání, 205 stran. ISBN: 978-80-246-3064-9.

Monografie Marka Loužka Evropská integrace z pohledu teorie veřejné volby je knihou z pomezí teorie mezinárodních vztahů a ekonomie. V tomto směru jde v českém prostředí o ojedinělý pokus, který by mohl přispět k racionalizaci diskusí o evropské integraci. Autor vůbec nezakrývá svá jednoznačná euroskeptická východiska. I přesto do domácího diskursu k této tematice přináší pohled, který (dalo by se říci, že konečně) dává diskusím nad existencí a vývojem Evropské unie daleko racionálnější rozměr, než jaký byl dosud obvyklý. I pro názorové odpůrce, pokud mají zájem diskutovat vědecky a nikoliv emočně, je Loužkův přínos blahodárný. Je zde poskytnut určitý aparát a myšlenkový konstrukt, v rámci kterého přestává být celý prostor úvah „,rejdištěm“ emocí v kontrapozicích „líbí - nelíbí “ (což není nic jiného, než kantovská volba vkusu, a tedy stojí mimo racionální diskusi), ale nabízí postupy, které díky analýze rozhodovacích procesů formulují integrační procesy jako výslednici paradigmat a zájmů národních států.

Kniha se člení do sedmi kapitol. První nastiňuje teorii mezinárodní politiky. Druhá líčí dějiny evropské integrace. Třetí popisuje proces rozšiřování versus opouštění ES/EU. Čtvrtá analyzuje ekonomii evropské integrace. Pátá zkoumá indikátory hlasovací síly v Evropské unii. Šestá kapitola diskutuje krizi eurozóny a sedmá migrační krizi.

První kapitola o teorii mezinárodní politiky má blízko k neorealistickým teoriím, pro něž je ústřední otázkou problém moci a rovnováhy. Nejdůležitější subjekty mezinárodních vztahů jsou státy, které sledují vlastní zájmy. Autor načrtává teorii racionální volby v mezinárodních vztazích a její zvláštní součást - teorii veřejné volby. Teorie racionální volby přináší na scénu individuální aktéry. Zatímco podle realistů si státy hájí především vlastní zájmy, v teorii racionální volby maximalizují hlavní aktéři včetně individuálních svůj užitek.

Druhá kapitola nově vykládá a interpretuje dějiny evropské integrace. Upozorňuje, že zakladatelé EHS nahlíželi na Římskou smlouvu jako zárodek budoucí „evropské vlády“. Autor zkoumá mezníky evropské integrace - jednotný evropský akt, Maastrichtskou smlouvu, Amsterdamskou smlouvu, Smlouvu z Nice, diskusi o evropské ústavě a Lisabonskou smlouvu. Loužek zde opakovaně podtrhuje své stanovisko, že jedním z triumfů evropského projektu bylo, že se mu podařilo vytvořit vlastní mýtus. Představa, že lékem na evropské problémy je stále těsnější integrace, je však podle Loužka mylná. Autor

* Luboš Smrčka (smrckal@vse.cz), Vysoká škola ekonomická v Praze, Fakulta podnikohospodářská. 
naopak formuluje a snaží se prokázat tezi, podle které zesilování integrace vede k růstu problémů a $\mathrm{k}$ menší schopnosti tyto problémy řešit.

Třetí kapitola věnuje pozornost rozšiřování versus opuštění EU. Autor konstatuje, že někteří uchazeči jsou soustavně odmítání (například Turecko), jiní naopak členství odmítají, ačkoli by o ně Unie měla zájem (Norsko a Švýcarsko). Mezi prohlubováním integrace a rozšiřováním společenství tak existuje určité napětí. Neustálým rozšiřováním Unie dochází k určité instituční těžkopádnosti, která se však stává argumentem pro posílení většinového hlasování.

Významnou pasáží především pro ekonomy je čtvrtá kapitola o ekonomii evropské integrace. Autor představuje tradiční přístupy k evropské integraci (federální a mezivládní) a načrtává „racionalistický“ model mezistátního vyjednávání amerického profesora Andrewa Moravcsika. Precizně vysvětleno je prohlubování evropské integrace, opominut není ani vliv zájmových skupin. Loužek zde opakovaně pracuje s paradoxem globalizace, podle něhož globalizace vyvolává politickou reakci, která ji odmítá.

Jádrem knihy je tedy z určitého pohledu kapitola pátá, ve které autor podrobuje detailnímu zkoumání hlasovací procesy v Evropské unii a dochází k několika velmi podnětným závěrům. Jedním z nich je zjištění, že rozšiřování Evropské unie snižuje výrazněji vliv malých (a středně velkých) zemí na konečná rozhodnutí, naopak vliv velkých států zůstal v principu zachován. Nebot' platí, že souhlasná stanoviska menších zemí $\mathrm{k}$ přijatým rozhodnutím či $\mathrm{k}$ projednávaným návrhům byla $\mathrm{v}$ předchozích etapách integrace sledovatelně častější než v etapě současné. Názor malých států a konečný zvolený postup Unie se dostávají do rozporu. Avšak obvyklost souhlasu velkých zemí zůstává při tomto srovnání dlouhodobě velmi podobný či stejný. Interpretace tohoto zjištění může být samozřejmě různá, lze si představit výklad velmi ,proevropský“ a stejně tak i výklad jednoznačně ,protievropský“. Autor ale především ze zjištěných průběhů hlasování vyvozuje, že rozhodovací procesy jsou s rozšiřováním Unie v určitém směru méně efektivní, nebot' souhlas s nimi je nižší než dříve. Zjednodušeně lze říci, že k získání dostatečného konsenzu je nutné formulovat složitější koalice, a to včetně potřeby „zabránit“"vzniku opačné koalice (blokační). Matematické postižení tohoto jevu je vskutku překvapivé.

Otevírá se zde velký prostor pro novou diskuzi k tématu rozhodovacích procesů tak složitých mechanismů, jakým je Evropská unie. Nebot’ pochopitelný pohled z pozice národních států (členských zemí) je jenom jednou z možností jak mechanismy rozhodování zkoumat. Vliv národních států na rozhodovací procesy je sice totiž nejzajímavější a nejvýraznější měřítko, nabízejí se ale i další. Bylo by opravdu podnětné, pokud by je někdo zvedl a podrobil stejně detailní analýze, jakou přinesl Marek Loužek. Primárně by jistě bylo vhodné pokusit se o něco podobného z hlediska „,ideových preferencí“ jednotlivých činitelů rozhodovacích procesů v dané době a daném prostréedí. Autor díky rozsáhlému statistickému a analytickému aparátu dospěl k určitým nesporně objektivním závěrům o hlasovací síle a skutečném významu národních států (o jejich podílech na různých rozhodnutích a jejich podílech na různých blokacích). Díky tomu je mohl porovnat s jejich jednoduchou relativní silou (prostý podíl hlasů vůči celkovému počtu). Bylo by však jistě přínosné vytvořit 
i model do určité míry souběžný, totiž podobně pečlivě modelovat vliv ideologických koncepcí na finální rozhodnutí (a pochopitelně také na blokace).

Ostatně Marek Loužek tyto otázky - i když spíše letmo - na řadě míst také zmiňuje, mimo jiné uvádí: „Ve skutečnosti paretovská efektivnost při evropském rozhodování není zaručena, protože země mohou být přehlasovány (při většinovém rozhodování), nebo změnit názor na projednávanou otázku, když se změní jejich národní vláda.“ (str. 196)

Lze tedy konstatovat, že Marek Loužek exaktně (nikoliv emotivně) prokázal, že rozhodovací procesy v rámci Evropské unie závisejí (do jisté míry bez ohledu na počet zemí) na relativně úzké skupině největších států. Jejich schopnost ovlivňovat rozhodovací procesy je podstatně vyšší, než odpovídá skutečnému počtu hlasů. To nutně navozuje řadu dalších otázek ohledně fungování celého systému. Zřejmě proto se rozhodl autor aplikovat svoje poznatky na dvě oblasti, které v posledních letech EU nejvíce poznamenaly a postavily ji před nejvíce „stresující“ rozhodování - tedy na krizi eurozóny a migrační krizi, přičemž určitá pozornost je věnována i otázce brexitu.

Zde stojí za zmínku, že tato pozornost vystoupení Velké Británie z Evropské unie je velmi uměřená a opravdu není možné ŕíci, že by Marek Loužek právě brexit nějakým zásadním způsobem přeceňoval. Což vzhledem $\mathrm{k}$ tomu, jak je často tento případ ze strany euroskeptiků ve veřejném prostoru používán coby důkaz o blížícím se konci EU, v podstatě překvapuje. Loužek je však zjevně daleko poučenější a konec konců se může opřít o své vlastní analýzy - zde lze asi najít pramen a logiku jeho nadhledu. To nic nemění na jeho nijak nezakrývaném euroskepticismu, kterému jinak dává vcelku jasné vyjádření, když např́klad píše: „Integrační instituce vykazují značnou míru rezistence proti změnám ve svůj neprospěch. Naopak velmi snadno dosahují posílení vlastních kompetencí. (...) EU čelí náhle čtyřem krizím: migrační krize, krize eurozóny, krize institucí a brexit. Není vyloučeno, že po sedmdesáti letech evropské integrace přichází éra dezintegrace. (...) Hlavním nahlédnutím teorie veřejné volby aplikované na EU je poznání, že k evropské integraci nedochází kvůli altruismu aktérů, nýbrž kvůli racionálnímu sledování individuálních nebo skupinových zájmů.“" (str. 196)

Zmíněna byla pozornost autora především ke krizi eurozóny a ke krizi migrační. U ní si jako př́klad hodný zkoumání bere problematiku „uprchlických kvót“ (přidělení určitého počtu uprchlíků konkrétním zemím na základě velikosti a ekonomické vyspělosti té které země), což je jako řešení v rámci EU považováno za „spravedlivé“ a přiměřeně solidární. Loužek nesouhlasí a s odkazem na jiné autory dává k diskuzi otázku prodeje víz (zpoplatnění pobytu). Odmysleme na chvíli „lidské“ rozměry věci a soustřed’me se na věc jako na ekonomický problém - pak tato otázka dostává nepoměrně racionálnější obrysy, nebot', jak Loužek zdůrazňuje, „stát může trvalý pobyt či občanství prodávat, což zajistí nejen to, že se do země dostanou migranti, pro něž to představuje největší prŕnos, ale bude to i výhodné pro státní pokladnu“. Určitou škodou publikace je, že v některých těchto „provokativních“ pasážích rezignuje na důkladnější analýzu okolností a průběhu rozhodovacích procesů, které se dané oblasti týkají. Ta by byla velmi užitečná. Možná by potvrdila to, co jinak celou knihou v podstatě kontinuálně prochází - totiž, že rozhodovací procesy týkající se evropské integrace a celoevropských témat trpí značnou 
rozředěností, což nutně vede k přijímání stále více „kompromisních“ řešení. Můžeme to formulovat i jako řešení „nejméně vyhraněných“. To také značí, že jsou v podstatě zapovězeny diskuze o řešeních překvapivých, konfliktních a celkově inovativních. Tuto emotivně formulovanou tezi by bylo možné pomocí aparátu, který autor shromáždil, dosti pravděpodobně potvrdit podstatně exaktnějšími postupy.

Celkově je možné monografii Marka Loužka popsat jako knihu, která by se měla stát standardní součástí diskuze o evropské integraci (či dezintegraci) a v tomto směru se s ní tak nebo onak budou muset vyrovnat jak eurooptimisté, tak i euroskeptici.

I když při posuzování práce Marka Loužka stále narážíme na její nesporný ideologický podtext, nelze přehlédnout fakt, že do analytických postupů zavádí určité pevné body související se samotnou použitou vědeckou metodou a s ideovými východisky, které však umožňují jakoukoliv příští diskuzi postavit na společný a pojmově jasný základ (,základová deska“). K těmto pojmům patří, pouze namátkou, např́íklad „,národní preference“ či „distribuční důsledky“. Ideje (deklarované politickými reprezentacemi či úřednickým aparátem Evropské unie) považuje Loužek v podstatě pouze za „krycí manévr“, centrem jeho pozornosti jsou proto ,zájmy“, což je z pohledu ekonomie a koneckonců i z pohledu autorem zvolených východisek přístup nepoměrně racionálnější a (at' již na věc máme názor jakýkoliv) diskutovatelný. Nebot's idejemi je to podobné jako se soudem vkusu - jsou věcí individuální. Zájmy lze definovat, kvantifikovat, ocenit, je možné je (alespoň rámcově) uchopit v rámci racionální diskuze. 